\title{
ОПИС КОРИСНОЇ МОДЕЛІ НА КЛІНІЧНИХ КАФЕДРАХ (ДЛЯ ОТРИМАННЯ ПАТЕНТУ УКРАЇНИ): АВТОРСЬКІ ПОГЛЯДИ
}

\author{
В. В. Чоп’як, А. Р. Вергун, О. Я. Яворська, О. М. Вергун \\ Львівський національний медичний університет імені Данила Галицького

\section{DESCRIPTION OF USEFUL (UTILITY) MODEL IN CLINICAL DEPARTMENTS (FOR THE PATENT OF UKRAINE): AUTHOR'S VIEWS} \\ V. V. Chopyak, A. R. Verhun, O. Ya. Yavorska, O. M. Verhun \\ Danylo Halytskyi Lviv National Medical University

\begin{abstract}
Формулювання структурної схеми опису для отримання Патенту України на корисну модель на клінічних кафедрах здійснене згідно з вимогами Державної служби інтелектуальної власності на основі стилістичного аналізу описів 12 патентів України, отриманих працівниками кафедр Львівського національного медичного університету імені Данила Галицького. Запропонований нами опис корисної моделі на клінічних кафедрах (для отримання Патенту України) сприятиме подоланню об'єктивних труднощів щодо адекватного послідовного описання клінічних спостережень, способів діагностики та лікування окремих захворювань згідно з вимогами, задекларованими для патентування.
\end{abstract} \\ The wording of the structural description of the circuit to obtain a patent of Ukraine in clinical departments is carried out in \\ compliance with the State Service of Intellectual Property, based of the stylistic analysis of descriptions of 12 patents of Ukraine \\ from the department of Danylo Halytskyi Lviv National Medical University. There was offered a description of the utility model \\ in the clinical departments (for the patent of Ukraine) will help to overcome the objective difficulties of adequate consistent \\ descriptions of clinical observations, methods of diagnosis and treatment of certain diseases in accordance with the declared \\ requirements for patent.
}

Вступ. Для отримання Патенту України необхідне проведення первинного аналізу на відповідність критеріям патентоспроможності відповідно до Закону України "Про охорону прав на винаходи (корисні моделі)” [6]. Патент на корисну модель різновид патенту, що видається за результатами формальної експертизи заявки. Термін дії патенту на корисну модель становить 10 років від дати подання заявки [1]; патенту, об'єктом якого є лікарський засіб, засіб захисту тварин, засіб захисту рослин тощо [2, 4], використання якого потребує дозволу відповідного компетентного органу, - може бути продовжено за клопотанням власника цього патенту на строк, що дорівнює періоду між датою подання заявки та датою одержання такого дозволу, але не більше ніж на 5 років [7].

Для виявлення аналогів і прототипів технічного рішення, яке патентується, інформаційний пошук здійснюється за офіційними опублікованими описами винаходів і корисних моделей до патентів України $[3,4]$ і за доступною інформацією щодо описів винаходів і корисних моделей до патентів Російської Федерації.

() В. В. Чоп’як, А. Р. Вергун, О. Я. Яворська, О. М. Вергун
Оформлення матеріалів заявки на видачу Патенту України на винахід (корисної моделі) [3] включає виявлення істотних ознак винаходу (корисної моделі); порівняння суттєвих ознак винаходу (корисної моделі) з ознаками аналогів; вибір прототипу для винаходу (корисної моделі), що патентується; складання формули винаходу (корисної моделі) (до 10 пунктів); формування опису винаходу (корисної моделі) [8].

Незнання стандартних формулювань, застосування коротких речень, перефразування, синоніми клінічних (та ін.) термінів призводять до сумбуру при оцінюванні таких робіт, унеможливлюють адекватне структурування реферату та формули корисної моделі, утруднюють оцінювання клінічної та патентної важливості опису і є причинами об'єктивного нерозуміння патентознавцем суті нововведення, що детермінує відхилення патенту.

Основна частина. Мета роботи - запропонувати структуровану схему формулювання клінічного опису згідно з вимогами Державної служби інтелектуальної власності для отримання Патенту України на корисну модель. 
Формулювання структурної схеми опису для отримання Патенту України на корисну модель на клінічних кафедрах здійснено згідно з вимогами Державної служби інтелектуальної власності на основі стилістичного аналізу 12 патентів України на корисну модель, отриманих працівниками кафедр сімейної медицини та дерматології, венерології, кафедри терапії № 1 та медичної діагностики Львівського національного медичного університету імені Данила Галицького за 5-річний (2010-2015) період.

У молодих науковців (магістрантів, дисертантів, здобувачів, аспірантів тощо) нерідко виникають об’єктивні труднощі щодо адекватного послідовного описання клінічних спостережень, способів діагностики та лікування окремих захворювань, згідно з вимогами, задекларованими для отримання Патенту України на корисну модель [5]. Недоліки таких описів (крім необгрунтованої синонімії) часто детермінуються незнанням особливостей алгоритмізації послідовності написання наукової роботи згідно з вимогами Державної служби інтелектуальної власності [3, 5].

Запропоновану нами структурну схему опису для отримання Патенту України на корисну модель на клінічних кафедрах сформульовано згідно з вимогами Державної служби інтелектуальної власності на основі стилістичного аналізу патентів України на корисну модель, які були прийняті до розгляду та отримали позитивні рішення. Основні (ключові) фрази у нашій схемі логічно написані жирним шрифтом; у деталізації жирний шрифт не застосовувався, ним виділено (в описі) обов’язкові фрази; курсивом позначено рекомендації до виконання; символом “[___ _ ]” відзначено можливу локалізацію літературних посилань.

Таким чином подаємо опис корисної моделі на клінічних кафедрах (для отримання Патенту України).

МПК (визначається патентознавцем)

Спосіб діагностики (лікування або ін.) основного захворювання на фоні фонового, супутнього захворювання 3 особливостями клінічних проявів та ускладненнями (жирним шрифтом)

Корисна модель належить до галузі медицини, а саме (яких галузей, спеціальностей), i може бути використана для діагностики (лікування тощо) основного захворювання на фоні фонового, супутнього захворювання 3 особливостями клінічних проявів та ускладненнями (копія назви патенту).

Патологія назва захворювання (основного) - це визначення [ ]. Як відомо, головними при- чинами виникнення (симптомами, проявами, ускладненнями тощо) перефраза назви патенту зі збереженням термінологічної автентичності є [__ ]. Дана патологія характеризується такими клінічними особливостями [__ ]. Для ефективної діагностики (лікування) даної категорії хворих найдоцільніше застосовувати опис загальноприйнятих методів, препаратів тощ, [__ ]. Складність (технічні труднощі, тяжкість діагностики, лікування) детермінують актуальність дослідження часткове або повне перефразування назви (теми) namенту [__ ] та пошук нових, вдосконалених шляхів (підходів, схем, алгоритмів тощо) діагностики та (або) лікування описаної патологї̈.

Найближчим аналогом корисної моделі, що заявляється, є загальновідомий комплексний спосіб діагностики (лікування тощо) основного захворювання (на фоні фонового, супутнього захворювання з особливостями клінічних проявів та ускладненнями) назва прототипу, (обов'язково патенту, фундаментальної монографії, фундаментальної статті, посібника тощо; перевагу слід надавати патенту або авторському свідоuтву) [ _ ]. Спосіб-прототип передбачає заходи діагностики, лікування, або ін., які не завжди можливо (доцільно) застосовувати при повторення або перефраза даних назви патенту. Недоліком (недоліками) цього відомого способу є описатu недоліки прототипу.

Дані недоліки адекватно усуваються корисною моделлю.

В основу корисної моделі поставлено завдання створити згідно з сучасними вимогами діагностики та (або) лікування (вказати основну патологію) спосіб назва патенту шляхом застосування короткий опис суті винаходу (одним реченням до 7-10 слів).

Поставлене завдання вирішується тим, що у способі лікування повторення або перефраза даних назви патенту, що включає надати спільні ознаки прототипу і пропонованого способу, проводять (здійснюють, виконують) опис суті винаходу (одним великим реченням у вигляді сумації послідовності думок, з застосуванням розділового знаку “;” при змістовому розриві окремих змістових ланок послідовності; розширена перефраза автентичної інформації попереднього абзацу. Іноді може виникати необхідність додаткового структурування з доповненнями, що реалізується застосуванням окремих абзаців та фрази "поставлене завдання вирішується також тим, що...”. 
Причинно-наслідковий зв'язок між сукупністю ознак запропонованої корисної моделі та досягнутим результатом детермінується, насамперед, особливостями підходу до діагностики (лікування) патології з урахуванням особливостей (клінічного перебігу, фонової та коморбідної патології, наявності ускладнень тощо) [

Позитивний результат, який передбачає клінічно очікувані положення, насамперед досягається (реалізується, детермінується) внаслідок описати теоретичні і практичні чинники позитивності результату [ ].

Спосіб лікування пролежнів м'яких тканин 3 колікваційним некрозом м'яких тканин та гнійними ускладненнями здійснюють таким чином. Після особливості підготовки до реалізації способу проводять наводиться поетапний, структурований, послідовний, алгоритмічний опис деталізованого виконання запропонованого способу.

Причинно-наслідковий зв'язок між сукупністю ознак корисної моделі і досягнутим результатом насамперед детермінується особливістю проведення (здійснення, реалізації тощо) наводиться теоретичне обгрунтування ефективності патенту [ ].

Результати апробації способу можна оцінити позитивно, враховуючи добру ефективність запропонованого лікування (діагностики та ін) проводиться попередній аналіз статистичних даних (подібно до розділу фахової статті “матеріали та методи дослідження").

\section{Список літератури}

1. Правила складання і подання заявки на винахід та заявки на корисну модель (затверджено наказом Мiністерства освіти і науки України 22.01.2001 р., № 22).

2. Мікульонок I. О. Інтелектуальна власність : навч. посіб. / І. О. Мікульонок. - К. : НТУУ “КПІ”, 2010. - 240 с.

3. Оформлення патентів на винаходи / уклад. : Ю. М. Кузнєцов, О. В. Литвин, В. Г. Кушик. - К. : НТУУ “КПІ” ; Тернопіль : ТДТУ, 1997. - 37 с.

4. How to get a European Patent Guide for Applicants (Як одержати європейський патент : посібник для заявників. Частина 1. Травень 2010 р. (13-та редакція) станом на
Було застосовано поетапну стратегію (послідовність, алгоритм тощо) діагностики (лікування тощо), згідно з корисною моделлю, яка адекватно реалізована у ... випадках проводиться аналіз статистичних груп та ефективності описаного способу, статистичних даних (подібно до розділу фахової статті “результати та обговорення”).

Перевагою нашого способу є врахування особливостей клінічного перебігу (етіології патогенезу, морфогенезу тощо, перефраз назви (теми) патенmy), що проявлялися описати чим [ ], які мають вплив на результати діагностики та (або) лікування описаної патології. Досягнуті клінічні результати описати які, на нашу думку, позитивно характеризують запропонований нами спосіб назва патенту та детермінують можливість його впровадження у вказати яку, де практику.

Висновок. Запропонований нами опис корисної моделі на клінічних кафедрах (для отримання Патенту України) на основі стилістичного аналізу описів 12 патентів України на корисну модель, отриманих працівниками кафедр Львівського національного медичного університету імені Данила Галицького, сприятиме подоланню об’єктивних труднощів щодо адекватного послідовного описання клінічних спостережень, способів діагностики та лікування окремих захворювань згідно з вимогами Державної служби інтелектуальної власності, задекларованих для отримання Патенту України на корисну модель.

01.05.2010 p.), Part 1. May 2010. - (13 ${ }^{\text {th }}$ edition). - Updated to 01.05 .2010 .

5. Складання і подання заявки на винахід і корисну модель. - http://cpsm.kpi.ua/Doc/Pat_DKR.pdf. - Заголовок з екрана.

6. https://broodex.com/ua/uk/intellectual/patent/utility//. Заголовок з екрана.

7. http://sips.gov.ua/ua/inventions.html. - Заголовок 3 екрана.

8. http://ua.unite.com.ua/inovation.php. - Заголовок 3 екрана. 